\title{
A STUDY ON PERSONALIZED BANKING SERVICES - A STEP TOWARDS RURAL DEVELOPMENT
}

\section{S. S. Mallikarjuna Prasanna}

\author{
Professor.
}

ABSTRACT Ever since the country gained independence, the Government of India has taken a plethora of measures for the development of rural areas along with the urban areas. This is perceptible from the first Five-year plan to the latest schemes announced by the Government, which distinguishably emphasize on rural development and enhancing farmers' income \& welfare. To achieve these aims, RBI gives directives to banks for development of rural areas and for opening of bank branches in these areas. Personalized services targeted for the rural residents will make them active participants in the banking sector and they will contribute towards the growth of the economy.

The objective of this research paper is to understand the preference of personalized services by bank customers residing in different areas of the Mysore and Tumkur. More than half of the population in Karnataka is residing in rural areas. The results of the study reveal that the urban bank customers have more preference for personalized services as compared to their rural counterparts and there is need to motivate the rural dwellers for utilizing more personalized banking services for their own development and for the development of the economy.

KEYWORDS : bank customers, finance, personalized services, rural areas

\section{INTRODUCTION}

To achieve the objectives of all-encompassing growth, RBI initiates various development programs and gives directives to banks for development of rural areas. As rural economy is mostly based upon agriculture and allied activities, their requirement for finance is different from those of urban areas. They need specialized products suitable for their requirements. Tailor-made banking services, specially designed according to their requirements, will assist them in carrying out their activities effectively and efficiently. Personalized services are essential for meeting the requirement of the rural residents and also to make them understand regarding finance.

Personalized banking services would also aid the financially illiterate rural folk in better managing their money with the help of professional financial consultancy services provided by the banks. For instance, there have been several cases in the Mysore and Tumkur, where the rural people came into windfall fortunes when their lands were acquired by industrialists or the government for setting up of factories, infrastructural projects etc. However, being financially illiterate, they could not manage their funds and soon exhausted all of it and endangered their future as they had already sold out their lands which were their only source of income. If such people had access to professional financial management services, they could have invested their fortunes wisely and secured their future with the substantial amount they obtained from the sale of their lands.

A personalized banking service not only satisfies bank customers but also delights them. Personalized banking services create an impression of special care and concern for bank customers. It creates an environment of trust which not only increases communication between the banks and their customers but also increase customers' loyalty towards their banks. A loyal customer becomes source of recurring income for the bank. Banking is a service-oriented industry and its existence depends upon the customers. So, providing them with world class services is necessity for the banks in this competitive environment of financial sector.

This paper is an effort to understand the preference of personalized services by bank customers residing in different areas of Mysore and Tumkur. As more than half of its population resides in rural areas, examining the choice of personalized services in this area becomes significant and can be extrapolated for understanding the preference for personalized banking services in the country as a whole.

\section{Literature Review}

A research study conducted by Manal Mansour Alharth etal. (2017) acknowledged the impact and attributes of the total quality management in banking services, reveals the significance and role of providing quality banking services to bank customers for enhancing the competitiveness of banks.

A study conducted in Nepal by Keshav Raj Bhatta and Bhanu Pratap Durgapal, (2016) aims to identify bank customers' perception about quality of service and customer satisfaction. Data is collected from 300 respondents from Mysore and Tumkur for this purpose. It found correlation between service quality dimensions and customer satisfaction.

A study was conducted in Ghana by Agbemabiese George Cudjoe (2015), on 120 respondents, the objectives of the study was to learn the effects of service quality on customer satisfaction in the Ghanaian banking industry. It took Ghana Commercial Bank as its research base. Five dimensions of SERVQUAL were applied to examine the data collected from respondents, under which the expectations and perceptions of GCB customers were studied. It reveals the effect of SERVQUAL on the quality of service. For better customer satisfaction, it proposes for excellent quality services to bank consumers.

A study was conducted in Algeria by HallouzWafaa and BenhabibAbderrezzak (2014), to identify the factors affecting customer satisfaction in banking sector. Sample size is 650 respondents of Algerian public sector banks. The results show that there exists significant relationship between good quality banking services and customer satisfaction

Amudha Ramachandran and Vijayabanu Chidambaram, (2012), conducted a study to recognize degree of customer satisfaction. The results disclose that customer satisfaction is affected by services of a bank provided on five scales of service encounters, waiting time of the customer, role of mediators, quality of service and handling of customer complaints by the bank. Their study proposed for maintaining long term customer relationships.

A study conducted by Canon Tong (2012) in Hong Kong on 306 respondents found out the effects of personalized banking services on customer satisfaction and loyalty. It found that there is important relationship between personalized services and consumer satisfaction. It also found that consumer satisfaction has direct influence on loyalty. 
3. OBJECTIVES OF THE STUDY

The main objective of the present research paper is to find out the preference for personalized banking services by bank customers residing in urban and rural areas.

\section{Research Area}

Mysore and Tumkur is the selected geographical area for the present research study. More than half of its population resides in rural areas and constitute an important segment of this area. It consists of 65 villages grouped into 11 village panchayats and 6 urban areas. Thus, results of the research carried out in this area can have implications at the national level.

\section{Hypothesis}

The hypothesis tested based on the primary data collected from the respondents is $\mathrm{H}_{0}=$ There is no significant difference in the preference for personalized banking services by the bank customers residing in urban and rural areas.

\section{Methodology}

The study is empirical in nature as data is collected from primary sources. For this purpose, structured questionnaires were distributed in 11 village panchayats and 6 urban areas of Mysore and Tumkur. Sample size of the study is 382 bank customers.

\section{Data Analysis and Interpretation}

The objective of the present study is to comprehend the choice for personalized services provided by the banks to their customers residing in different areas. a variety of statistical tools and techniques are used on data collected from respondents. In the present research paper, percent analysis and Independent Samples T-Test are used for analysis and interpretation of data with the help of SPSS software.

\subsection{Demographic Variable: Residential Ārea}

The data is collected from a total of 382 respondents, out of which 69 percent residing in rural areas whereas resident of urban area constitutes 31 percent of total sample size. The analysis of the data shows that the number of rural residents is more than that of the urban residents.

\subsection{Selection of Personalized Services in different residential groups}

The research study reveals that urban residents have more choice of personalized services as compare to rural residents. Out of total urban residents 60 percent prefer personalized services. This percentage is 41 percent in case of rural residents who opt for personalized services which is less that 50 percent. This may be due to less awareness of personalized services among rural population. Table No. 1 presents the above statistics.

Table No. 1 Preference of Personalized Services in Different Residential Areas

(Figures are in percent)

\begin{tabular}{|c|c|c|c|}
\hline Residential Area (in years) & Yes & No & Total \\
\hline Urban & 60 & 40 & 100 \\
\hline Rural & 41 & 59 & 100 \\
\hline
\end{tabular}

\section{Source: Primary Dato}

To identify with the probable differences existing in the preference of personalized service of banks by urban and rural bank customers, collected data was investigated through testing the hypothesis. Statistical technique Independent Samples T-Test is applied on the collected data, results into Table No. 2 and 3.

\section{Table No. 2 Mean Value Analysis- Residential Area}

\begin{tabular}{|c|c|c|c|c|}
\hline Area & $\mathrm{N}$ & Mean & Std. Deviation & Std. Error Mean \\
\hline Urban & 117 & 1.40 & .492 & .046 \\
\hline Rural & 265 & 1.59 & .492 & .030 \\
\hline
\end{tabular}

Mean value of rural bank customers is 1.59, which is higher than mean value of urban bank customers at 1.40 as revealed by Table no.2. This shows that bank customers dwelling in rural areas have desire for more personalized services as compare to their urban counterparts.

Table No. 3 Residential Area - Independent Samples T-Test

\begin{tabular}{|l|c|c|c|c|c|c|c|}
\hline Personalized Banking Services & \multicolumn{2}{|c|}{ Levene's Test for Equality of Variances } & \multicolumn{4}{|c|}{ T-test for Equality of Means } \\
\cline { 2 - 8 } & $\mathrm{F}$ & Sig. & $\mathrm{t}$ & Df & $\begin{array}{c}\text { Sig. } \\
\text { (2-tailed) }\end{array}$ & $\begin{array}{c}\text { Mean } \\
\text { Difference }\end{array}$ & $\begin{array}{c}\text { Std. Error } \\
\text { Difference }\end{array}$ \\
\hline Equal variances assumed & .047 & .829 & -3.490 & 380 & .001 & -.191 & .055 \\
\hline Equal variances not assumed & & & -3.490 & 222.0 & .001 & -.191 & .055 \\
\hline
\end{tabular}

As per above table, sign. Value is 0.001 (2-tailed) which is less than 0.05 (at 95 percent confidence interval). It signifies that there exists significant difference in preference of personalized services of banks by bank customers or urban and rural areas. Thus, $\mathrm{H}_{0}$ is rejected.

\section{Suggestions}

The results of the study reveal that, in rural areas, preference for personalized banking services is very less. It can be increased by creating awareness among the rural people. When they will be well informed about availability of personalized services, only then they can avail the benefit of these services. Ignorant customers cannot demand personalized services because they have no knowledge about their availability. Creating well informed environment in rural areas is an urgent requirement which the banks should work towards. For this purpose, organizing outreach camps in rural areas can be helpful. Information should be provided in native language of rural residents for more understanding and better retention. Financial consultancy services should be provided as part of personalized services, so as to help the rural people in managing their finances in a better manner. Helping rural people in managing their finance, on an individual basis, will help them in investing their funds wisely and securing their and their family's future. It will help them to grow which will ultimately help the economy to grow.

\section{CONCLUSION}

The outcome of the research shows that highlighting the need for personalized services will help bank customers in managing their finances better. It will safeguard their future and will help them to lead a prosperous life. Also, it will bring more business for the banks and help in development of the banking sector.

\section{REFERENCES}

1. Alharth Manal Mansour et. al. (2017) "The Total Quality Management in Banking", International Advanced Research Journal in Science, Engineering and Technology, ISSN (Online) 2393-8021 ISSN (Print) 2394-1588, Vol. 4, Issue 5. May 2017, pp 159-163.

2. Bhatta Keshav Raj and Durgapal Bhanu Pratap, (2016) "Service Quality Perceptions and Customer Satisfaction in Nepalese Banking Sector" Indian Journal of Commerce \& Management Studies ISSN: 2249-0310 EISSN: 22295674, Volume VII Issue 1, Jan. 2016, pp 17 to 2.

3. Cudjoe Agbemabiese George et. al. (2015), "Service Quality and Customer Satisfaction in the Ghanaian Banking Industry (A Case of Ghana Commercial Bank)", European Journal of Business and Management, ISSN 2222-1905 (Paper) ISSN 2222-2839 (Online) Vol.7, No.3, 2015, pp 123 to 140.

4. Ramachandran Amudha and Chidambaram Vijayabanu, (2012), "A review of customer satisfaction towards service quality of banking sector", Periodicapolytechnica Social and Management Sciences, 20/2 (2012) 71-79.

5. Tong Canon, et. al. (2012), "The Influences of Service Personalization, 
Customer Satisfaction and Switching Costs on E-Loyalty", International Journal of Economics and Finance, Vol. 4, No. 3; March 2012, pp 105-117.

6. WafaaHallouz and AbderrezzakBenhabib (2014), "A Study of the

Relationship between Banking Service Quality and Customer Satisfaction in

Algerian Public Banks" International Journal of Science and Research (IJSR),

ISSN (Online): 2319-7064, Volume 3 Issue 1, January 2014, pp 272-278. 